\title{
Recent expansion of dengue virus serotype 3 in West Africa
}

L Franco (francolet@isciii.es) ${ }^{1,2}$, A Di Caro ${ }^{3,2}$, F Carletti ${ }^{3}, 0$ Vapalahti4,2, C Renaudat ${ }^{5,2}$, H Zeller ${ }^{6}$, A Tenorio ${ }^{1,2}$

1. National Centre for Microbiology, Instituto Carlos III, Madrid, Spain

2. European Network for Imported Viral Disease - Collaborative Laboratory Response Network (ENIVD-CLRN). www.enivd.org

3. National Institute for Infectious Diseases 'Lazzaro Spallanzani’, Rome, Italy

4. Haartman Institute and Dept of Veterinary Biosciences, University of Helsinki, Finland

5. National Reference Centre for Arboviruses, Institut Pasteur, Paris, France

6. European Centre for Disease Prevention and Control, Stockholm, Sweden

Citation style for this article:

Citation style for this article: Franco L, Di Caro A, Carletti F, Vapalahti O, Renaudat C, Zeller H, Tenorio A. Recent expansion of dengue virus serotype 3 in West Africa. Euro Surveill. 2010;15(7):pii=19490. Available online: http://www.eurosurveillance.org/ViewArticle.aspx?Articleld=19490

This article has been published on 18 February 2010

Due to non-existing or limited surveillance in Africa, little is known about the epidemiology of dengue illness in the continent. Serological and virological data obtained from returning European travellers is a key complement to this often flawed information. In the past years, dengue 3 virus has emerged in West Africa and has been detected in travellers returning to Europe. The first dengue epidemic in Cape Verde with more than 17,000 cases from September to December 2009 demonstrated that dengue virus is still expanding worldwide to new territories.

\section{Introduction}

Dengue virus is widely distributed in tropical and subtropical countries and is transmitted by day-biting mosquitoes of the genus Aedes. It often goes unrecognised in African countries, where the lack of surveillance systems, or their poor implementation, is the cause of missing information on dengue virus activity [1].

Laboratory-based surveillance of dengue virus infection in febrile travellers could provide useful information about the different dengue virus serotypes circulating worldwide and in particular those circulating in areas where limited surveillance is available. To this end, the European Network for Imported Viral Disease - Collaborative Laboratory Response Network (ENIVD-CLRN network) provides outbreak support, in particular related to laboratory diagnostics, to assist European Union (EU) Member States, candidate countries and members of the European Economic Area and European Free Trade Association (EEA/EFTA) in detecting, investigating and responding to outbreakprone diseases, imported, rare or unknown infectious agents, or outbreaks related to the intentional release of pathogens.

A large outbreak of dengue illness with more than 17,000 cases occurred in the Cape Verde archipelago at the end of 2009 [2]. It was the first time that dengue virus was detected in the archipelago. Concomitant detection of dengue virus in Senegal and identification of several imported cases among travellers returning from West Africa were reported. This article provides a brief review of historic reports of dengue virus in Africa focused on West Africa and summarises the recent outbreaks and the links to imported cases of dengue virus infection in Europe.

\section{Dengue virus in West Africa}

The burden of dengue virus infection in Africa has not been estimated yet. Outbreaks of dengue fever and dengue haemorrhagic fever are poorly documented, however, we cannot conclude that mild and severe dengue infection is infrequent in African countries. The circulation of different dengue virus serotypes is also poorly documented. Nevertheless some information is provided in publications on outbreaks and serosurvey studies in Africa and reports involving dengue virus infection in travellers.

A retrospective serological study in 1956 [3] suggests that dengue virus caused an epidemic in Durban, South Africa in 1927. This report is the first documented dengue virus epidemic in Africa. It was not until the end of the 1960s, however, that the virus responsible for dengue fever outbreaks in Africa could be isolated. The first dengue virus (DENV) isolate was DENV-1, detected in Nigeria in 1964 [4]. Since then DENV-1, 2 and 4 have been circulating in West Africa although the main serotype reported has been DENV-2 [1]. Viral isolates have been predominantly detected in wild-caught mosquitoes (Aedes luteocephalus, Ae. taylori and/or Ae. furcifer) involved in sylvatic transmission cycles in Senegal and Nigeria, and from a few cases in humans who were in contact with forest cycles $[5,6]$. DENV-2 from sylvatic cycles have also been isolated in Côte d'Ivoire, Burkina Faso and Guinea $[5,7,8]$. More recently in 2005, DENV-2 was identified in a traveller returning from Ghana [9]. The last detection of DENV-4 in West Africa was in the 1980 s in two inhabitants of Dakar, Senegal [10]. 
The first description of DENV-3 activity in Africa was related to outbreaks detected during 1984 and 1985 in Pemba, Mozambique, with two deaths due to dengue haemorrhagic fever [11]. DENV-3 was then detected in 1993 in Somalia and areas around the Persian Gulf [12]. Phylogenetic studies suggested that these outbreaks were caused by a virus imported from the Indian subcontinent [13]. DENV-3 circulation in West Africa was first identified in a traveller returning to Spain from Cameroon in 2006 and subsequently in a traveller returning to Spain from Senegal in 2007 (C. Domingo et al., unpublished results). However the first article on DENV-3 in West Africa was published in 2008, when DENV-3 was detected co-circulating with yellow fever in Côte d'Ivoire [14].

\section{Dengue virus importation from Africa into Europe}

Reports on the importation of dengue virus to Europe have been increasing since the 1990s. Some of these are publications or reports from single countries or networks and show that the frequency of travel-acquired

\section{FIGURE 1}

West African countries where dengue serotypes have been identified in recent years (2006-2009)

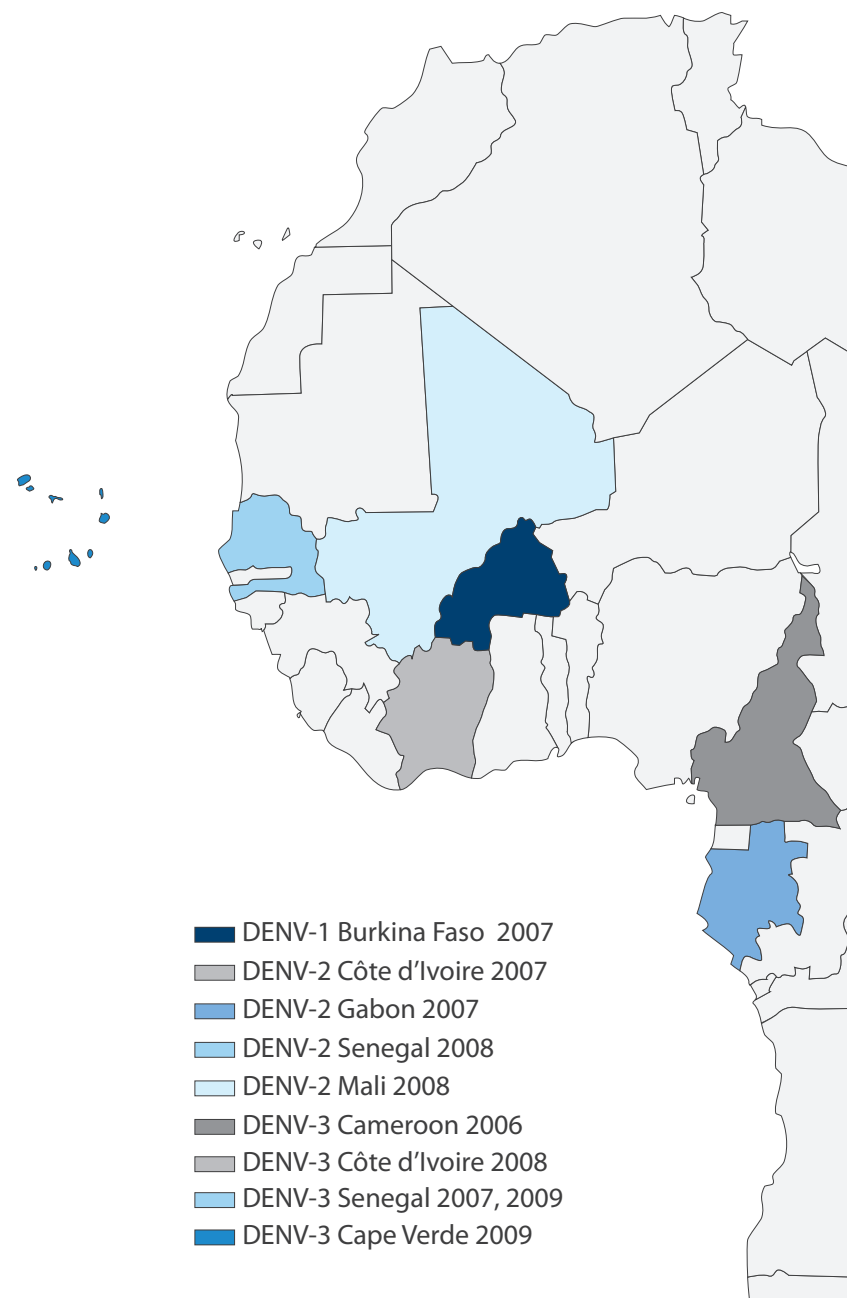

DENV: dengue virus.

Sources: ENIVD-CLRN, INVS (France), WHO, ECDC. dengue virus infections in Africa is low compared to south-east Asia and the Americas [15,16]. This distribution is due to two main factors: worldwide dengue virus activity and the popularity of certain countries as tourist destinations. In a study by the European Network on Imported Infectious Disease Surveillance (TropNetEurop) covering 481 European travellers between 1999 and 2002, 8\% of dengue fever cases were imported from Africa [17], a proportion similar to that found in other European studies. In France, between 2002 and 2005, 14\% of imported dengue fever cases originated in Africa [18]. Ten per cent of the cases in Austrian and Finnish travellers were also acquired in Africa, as analysed over a 15-year (19902005) and 10-year (1999-2009) period, respectively $[19,20]$. In 2008, dengue virus cases imported from Africa reported by TropNetEurop dropped to 4\% [21].

\section{Dengue virus importation from \\ West Africa (2006-2008)}

In recent years, dengue fever has been documented in travellers returning from several West African countries, caused in particular by DENV-3 which was recently identified in that region (Figure 1 ).

From January 2006 to August 2008, 19 imported cases of dengue virus infection were reported in travellers from West Africa in France: 11 cases from Côte d'Ivoire (one in 2006, three in 2007 and seven in 2008), four cases in Burkina Faso (one in 2006 and three in 2007), two cases in Benin in 2006, one case in Senegal in 2007 and one case in Mali in 2008 [22]. Dengue serotypes detected during this period were DENV-1 in Burkina Faso [22], DENV-2 in Côte d'Ivoire [22] and DENV-2 in a simultaneous outbreak of chikungunya and dengue viruses in Gabon [23], all in 2007. In 2008, DENV-2 serotype was identified in Mali [14] and in Senegal [24]. Moreover, DENV-3 was detected in a Japanese tourist and in a French expatriate returning from Côte d'Ivoire between May and July 2008 [25]. DENV-3 activity was also detected in East Africa in 2008 in a Finnish traveller returning from Eritrea (O. Vapalahti, personal communication).

\section{Recent DENV-3 activity in West Africa}

In the beginning of October 2009, a case of dengue fever was reported in a Senegalese returning to Italy after a holiday in his home country. DENV-3 infection was diagnosed at the National Institute for Infectious Diseases in Rome [26]. At the same time France reported DENV-3 in travellers returning from Senegal (C. Renaudat, personal communication). Also, ProMED posted several archives describing dengue virus outbreaks in Senegal: in the Kedoungo region [27] and Dakar [28]. The Pasteur Institute in Dakar identified DENV-3 in febrile patients (A. Sall, personal communication).

Meanwhile, an unprecedented outbreak has been detected in the Cape Verde archipelago in the beginning of September 2009 (week 40) [29]. This is the first 
report of dengue virus activity in that country (Figure 1). The highest number of cases were reported during week 45 (5,512 cases), decreasing in week 47 to 1,447 cases and finally five cases in week 53 . A total of 17,224 cases including six deaths were reported from 18 of the 22 municipalities in Cape Verde by the end of 2009. The municipality of Praia on Santiago island, notified the highest number of cases $(13,000$ cases) followed by Sao Felipe in Fogo Island (3,000 cases) [2]. The first samples tested at the Pasteur Institute in Dakar confirmed DENV-3 circulation [29].

Recently imported DENV-3 cases in Europe and the identified outbreaks in West Africa suggest that this serotype is spreading in the region.

We used a phylogenetic approach in order to determine genotype association among the recent DENV-3 circulating in the region, using sequences provided by ENIVD-CLRN laboratories. DENV-3 viruses are divided into four geographically different genotypes (I, II, III, and IV) [13]. The emergence of a virulent lineage of genotype III in Sri Lanka at the end of 1980 s was largely associated with a high incidence of the disease and the emergence of Dengue haemorrhagic fever in Asia and the Americas. All DENV-3 detected in East Africa from 1984 to 1993 [13] belonged to this lineage of genotype III (Figure 2).

Also, isolates from geographically distant outbreaks, strains ENIVD Spain ex Cameroon 2006, Japan ex Ivory Coast 2008 and Saudi Arabia 2004 (Figure 2), and from Eritrea in 2008 (not shown in Figure 2; E. Huhtamo et al, unpublished results) belong to DENV-3 genotype III. The DENV-3 strain that circulated in Senegal in 2009 and was isolated from a traveller in Italy [26], also belonged to genotype III and was closely related to the DENV-3 strain circulating in Côte d'Ivoire in 2008. Therefore, the DENV-3 that has emerged in the Cape Verde archipelago is likely to have been introduced from a West African country due to the geographical proximity with strong trade and travel activities.

\section{Future outlook}

The recent DENV-3 expansion in West Africa was first detected in European travellers returning from this area, which triggered the alert for active surveillance in the exporting countries.

\section{FIGURE 2}

Phylogenetic tree of DENV-3 sequences

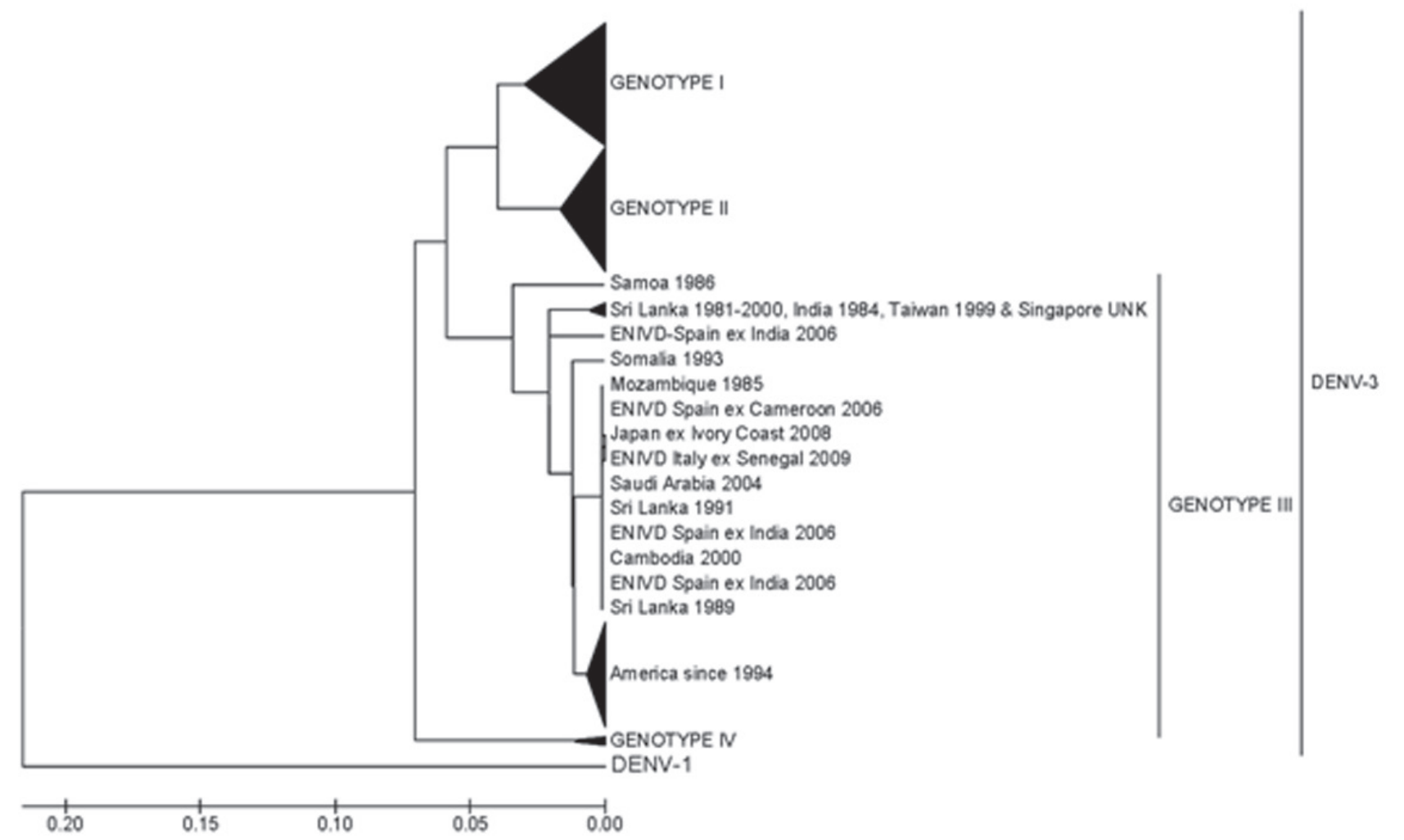

This tree is based on a 139 nt fragment of the E gene. Sequence identification is as follows: country of origin, year of identification. The sequences from imported cases are labelled as ENIVD/country of detection/country of exportation/year of detection. Phylogenetic analysis was conducting using MEGA 4.0 (Tamura, Dudley, Nei, and Kumar 2007). Genetic distance was calculated with the Tamura Nei algorithm. Phylogentic tree was constructed using Neighbor-Joining model and the resultant tree was tested by Bootstrap (1,00o Replicates). Only bootstrap probabilities over $60 \%$ are shown. 
However, although most of the African countries are prepared for surveillance of yellow fever and human immunodeficiency virus infections, most of them lack specific methods for dengue virus diagnostics and require new diagnostic tools. As a recent example of such technology transfer, the Pasteur Institute laboratories in Paris and Dakar have implemented differential diagnostics for dengue at the Pasteur Institute in Abidjan [14]. This model of cooperation is required also in other African countries.

As long as active dengue virus surveillance is poorly implemented in Africa, the study of febrile travellers returning to Europe could help to detect viral activity on the African continent.

As part of the ENIVD-CLRN, a collaborative study on imported chikungunya and dengue virus infections in European travellers will start in 2010. The aim of the study is to complete the global map of chikungunya and dengue virus circulation, including the global distribution of viral genotypes of those viruses. It will permit clinicians to compare the clinical symptoms, signs and analytical data of imported cases in Europe. The surveillance of travellers returning to Europe will continue to improve our knowledge about dengue virus distribution in Africa.

\section{References}

1. Sang RC. Dengue in Africa. Nairobi, Kenya, Arbovirology/Viral Haemorrhagic Fever Laboratory, Centre for Virus Research, Kenya Medical Research Institute, 2007. Available from: http:// www.tropika.net/review/061001-Dengue_in_Africa/article.pdf. [Accessed 210ctober 2009].

2. Cape Verde Ministry of Health. [Internet]. Dengue: Follow the outbreak [Portuguese]. Available from: http://http://www. dengue.gov.cv

3. Kokernot RH, Smithburn KC, Weinbren MP. Neutralizing antibodies to arthropod-borne viruses in human beings and animals in the Union of South Africa. J Immunol. 1956;77(5): 313-23.

4. Carey DE, Causey OR, Reddy S, Cooke AR. Dengue viruses from febrile patients in Nigeria,1964-68. Lancet. 1971;1(7690):105-6.

5. Vasilakis N, Holmes EC, Fokan EB, Faye O, Diallo M, Sall AA, et al. Evolutionary process among sylvatic dengue type 2 viruses. J. Virol. 2007;81(17):9591-5.

6. Vasilakis N, Tesh RB, Weaver SC. Sylvatic dengue type 2 activity in humans, Nigeria 1966. Emerg Infec Dis. 2008;14(3):502-4.

7. Zeller HG, Traoré-Lamizana M, Monlun E, Hervy JP, Mondo M, Digoutte JP. Dengue-2 virus isolation from humans during an epizootic in southeastern Senegal in November, 1990. Res Virol. 1992;143(2):101-2.

8. Diallo M, Ba Y, Sall AA, Diop OM, Ndione JA, Mondo M, et al. Amplification of the sylvatic cycle of dengue virus type 2 Senegal, 1999-2000: Entomologic findings and epidemiologic considerations. Emerg Infect Dis. 2003;9(3):362-7.

9. Huhtamo E, Uzcátegui N, Siikamäki H, Saarinen A, Piiparinen $\mathrm{H}$, Vaheri A, et al. Molecular epidemiology of dengue virus strains from Finnish Travelers. Emerg Infect Dis. 2008;14(1):80-3.

10. Saluzzo JF, Cornet M, Castagnet P, Rey C, Digoutte JP. Isolation of dengue 2 and dengue 4 viruses from patients in Senegal. Trans R Soc Trop Med Hyg. 1986;80(10):5.

11. Gubler DJ, Sather GE, Kuno G, Cabral JR. Dengue 3 virus transmission in Africa. Am J Trop Med Hyg. 1986;35:1280-4.

12. Sharp TW, Wallace MR, Hayes CG, Sanchez JL, DeFraites RF, Arthur RR, et al. Dengue fever in US troops during Operation Restore Hope, Somalia, 1992-1993. Am J Trop Med Hyg. 1995;53:89-94.
13. Messer WB, Gubler DJ, Harris E, Sivananthan K, De Silva AM. Emergence and global spread of dengue serotype 3, Subtype III virus. Emerg Infec Dis. 2003; 9(7):800-9.

14. Dengue in Africa: emergence of DENV-3 Cote d'Ivoire, 2008. [No authors listed]. WHO Wkly Epidemiol Rec.2009; 84(1112):85-8. Article in English, French.

15. Wichmann 0, Jelinek T. Dengue in travelers: a review. J Travel Med. 2004;11(3):161-70.

16. Schwartz E, Weld LH, Wilder-Smith A, von Sonnenburg F, Keystone JS, Kain KC, et al. Seasonality, annual trends, and characteristics of dengue among ill returned travelers, 19972006. Emerg Infect Dis. 2008;14(7):1081-8.

17. Wichmann O, Muhlberger N, Jelinek T. Dengue-the underestimated risk in travellers. Dengue Bull. 2003; 27:126-37.

18. Tarantola A, Quatresous I, Ledrans M, Lassel L, Krastinova E, Cordel H, et al. [Imported cases of dengue fever diagnosed in metropolitan France, from January 2001 to December 2006]. Med Mal Infect. 2009;39(1):41-7. French.

19. Laferl H, Szell M, Bischof E, Wenisch C. Imported dengue fever in Austria 1990-2005. Travel Med Infect Dis. 2006;4(6):319-23.

20. Huhtamo E, Hasu E, Uzcátegui NY, Erra E, Nikkari S, Kantele A, et al. Early diagnosis of dengue in travelers: Comparison of a novel real-time RT-PCR, NS1 antigen detection and serology. J Clin Virol. 2010;Jan;47(1):49-53.

21. Jelinek T. Trends in the epidemiology of dengue fever and their relevance for importation to Europe. Euro Surveill. 2009;14(25). pii=19250. Available from: http://www.eurosurveillance.org/ ViewArticle.aspx?Articleld $=19250$

22. Institut de Veille Sanitaire, France. Bulletin Hebdomadaire International. 2009; №151 (Accessed 17 November 2009). Available from: http://www.invs.sante.fr/international/bhi/ bhi_120808.pdf. French.

23. Leroy EM, Nkogue D, Ollomo B, Nze-Nkogue C, Becquart $P$, et al. Concurrent chikungunya and dengue virus infectious during simultaneous outbreak, Gabon, 2007. Emerg Infect Dis. 2009;15(4):591-3.

24. European Centre for Disease Prevention and Control (ECDC). [Internet]. Dengue in West Africa, 2009. Available from: http:// ecdc.europa.eu/en/healthtopics/Pages/Dengue_Fever.aspx

25. Ninove L, Parola P, Baronti C, De Lamballerie X, Gautret $P$, Doudier $B$, et al. Dengue virus type 3 infection in traveller returning from west Africa. Emerg Infect Dis. 2009;15(11):1871-2.

26. Nisii C, Carletti F, Castilletti C, Bordi L, Meschi S, Selleri M, et al. A case of dengue type 3 virus infection imported from Africa to Italy, October 2009. Euro Surveill. 2010;15(7): pii=19487. Available from: http://www.eurosurveillance.org/ViewArticle. aspx?Articleld $=19487$

27. ProMED-mail. Dengue/DHF Update 2009 (40). Archive number 20091005.3454.5 October 2009. Boston US: International Society for infectious diseases. Available from: http://www. promedmail.org

28. ProMED-mail. Dengue/DHF Update 2009 (48). Archive number 20091123.4016. 23 November 2009. Boston US: International Society for infectious diseases. Available from: http://www. promedmail.org

29. World Health Organization (WHO). Weekly epidemiological record. Dengue fever in Cape Verde. WHO Wkly Epidemiol Rec. 2009;84:469. Available from: http://www.reliefweb.int/rw/ RWFiles2009.nsf/FilesByRWDocUnidFilename/JBRN-7XJJBZfull_report.pdf/\$File/full_report.pdf 